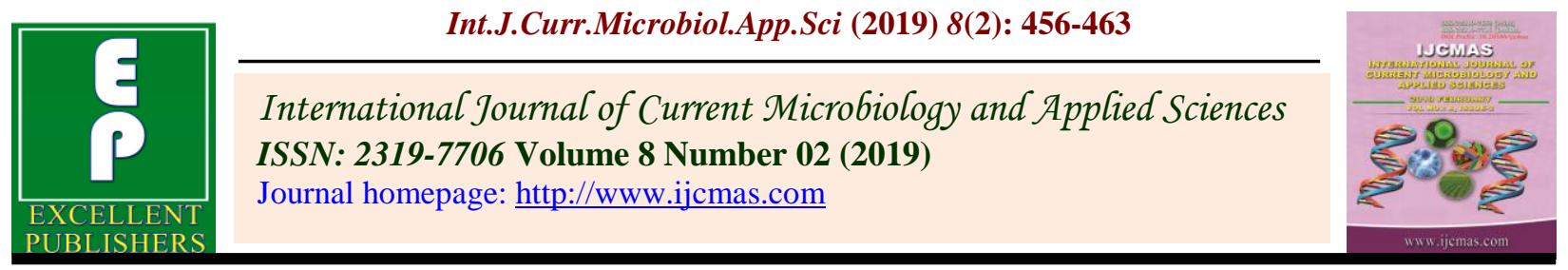

Original Research Article

https://doi.org/10.20546/ijcmas.2019.802.051

\title{
Effect of Seeding Interval and Transplanting Age on Seed Yield and Seed Quality in KRH-4 Hybrid Rice
}

\author{
B. Madhukeshwara*, Puttappanavara, V.K. Deshpande, \\ A. Krishna and N.G. Hanumaratti \\ Department of Seed Science and Technology, University of Agricultural Sciences, \\ Dharwad-580 005, Karnataka, India \\ *Corresponding author
}

\begin{tabular}{|c|c|}
\hline & A B S T R A C T \\
\hline Keywords & \multirow{4}{*}{$\begin{array}{l}\text { A field experiment was conducted during } 2016 \text { and } 2017 \text { at Agricultural Research Station, } \\
\text { Malagi, UAS, Dharwad to know the effect of seeding interval and transplanting age on } \\
\text { seed yield and seed quality in KRH- } 4 \text { hybrid rice. The results revealed that, the } \\
\text { transplanting of seedlings at the age of } 18 \text { days recorded the highest number of productive } \\
\text { tillers }(9.47 \text { and } 10.52) \text {, highest seed yield per hectare }(838 \mathrm{~kg}, 888 \mathrm{~kg} \text { ) whereas, the early } \\
\text { sowing of pollen parent by } 2 \text { days ensured better synchrony with higher seed set per cent } \\
(18.11 \%, 18.54 \%) \text { and seed yield per hectare }(1170 \mathrm{~kg}, 1225 \mathrm{~kg}) \text {. The } 18 \text { days old } \\
\text { seedlings registered the higher seed quality parameters like germination percentage } \\
(96.53 \% \text { and } 97.60 \%) \text { and seedling vigour index ( } 2734 \text { and } 2858) \text {. The study indicated that } \\
\text { transplanting of seedlings at the age of } 18 \text { days together with early staggering of pollen } \\
\text { parent by } 2 \text { days to female parent ensures higher seed set and seed yield in KRH-4 hybrid } \\
\text { rice under zone } 9 \text { (hilly zone) of Karnataka. }\end{array}$} \\
\hline $\begin{array}{l}\text { Hybrid Rice, Seed } \\
\text { quality, Seeding } \\
\text { interval, } \\
\text { Synchronization, } \\
\text { Transplanting age }\end{array}$ & \\
\hline Article Info & \\
\hline $\begin{array}{l}\text { Accepted: } \\
\text { 07 January } 2019 \\
\text { Available Online: } \\
\text { 10 February } 2019\end{array}$ & \\
\hline
\end{tabular}

\section{Introduction}

"Rice is life" was the theme of International year of rice, 2004 that reflects the importance of rice, which holds the key to our country's ability to produce enough food for our people. The food security of India and other countries is now at risk due to increase in population. By 2050, population of India is expected to be 1.6 billion from the current level of 1.1 billion. This implies a greater demand for food. Although, the world as a whole may have sufficient food for everyone, it would need to be produced in the region itself due to socio-economic and political compulsions. To safeguard and sustain the food security in India, it is important to increase the productivity of rice under limited resources. So the technologies followed in India need to be constantly updated to meet the challenge of food security. Since the yield of high yielding varieties of rice is plateauing, it is rather difficult to achieve this target with the present day inbred varieties. Therefore, to sustain the self sufficiency in rice, additional production of 1.5 million tons is needed every year. Among the limited options, hybrid technology is the only proven technology currently 
available for stepping up rice production significantly. Seed yield of rice depends on its genetic potential, agro-climatic conditions and management practices. The age of seedlings at transplanting is an important criterion in rice production as it primarily contributes to the number of tillers produced per hill. Tillering behavior of the rice plant greatly depends on the age of seedling at transplanting. Transplanting of healthy seedlings of optimum age ensures better rice yield. Among the production factors, major barrier in hybrid seed production is to achieve perfect synchronization of flowering between female and male parental lines and the non uniformity in flowering period of both male and female parents' results in non-availability of pollen from the male parent at the time of stigma receptivity in female parent leading to poor seed set. To achieve proper synchronization of flowering of male and female parents cultural practices are followed (Virmani and Sharma., 1993). Staggering or seeding interval is yet another major technique which needs attention in the hybrid rice seed production where in the parental lines differing in their growth duration can be sown on staggered dates in the nursery beds, so that they come to flowering at the same time in the main field where hybrid seed is to be produced. This is referred as 'staggered' or 'differential' sowing. In spite of adjusting the sowing date, the parents do not flower at a time because of the differential response of the parents to the change in environmental conditions (Biradarpatil and Shekhargouda, 2006). Keeping the above points in view, the investigation on effect of seeding interval and transplanting age on seed yield and seed quality in KRH-4 hybrid rice was undertaken.

\section{Materials and Methods}

The field experiment was carried out at the Agricultural Research Station Malagi, UAS, Dharwad during kharif 2016 and kharif 2017 to evaluate the effect of seeding interval and transplanting age on seed yield and seed quality in KRH-4 hybrid. The experiment was laid out in two factorial randomized block design with 10 treatment combinations. Factor one consisted of transplanting age of seed parent viz., $\left(\mathrm{A}_{1}\right)$ : transplanting of seedlings at the age of 18 days, $\left(\mathrm{A}_{2}\right)$ : transplanting of seedlings at the age of 25 days. Factor one consisted of five seeding intervals of pollen parent namely, $\left(S_{1}\right)$ : same day planting of both $A$ and $R$ lines, $\left(S_{2}\right)$ : early sowing of $\mathrm{R}$ line by 2 days, $\left(\mathrm{S}_{3}\right)$ : early sowing of $\mathrm{R}$ line by 4 days, $\left(\mathrm{S}_{4}\right)$ : early sowing of $\mathrm{R}$ line by 6 days, $\left(\mathrm{S}_{5}\right)$ : early sowing of $\mathrm{R}$ line by 8 days and replicated thrice. The parental seeds, CRMS 32-A (male sterile line) and MSN 36-R (restorer line) of KRH-4 hybrid rice were collected from the Zonal Agricultural Research Station, Mandya. The foliar seedlings were raised by sowing in wet nursery bed and transplanted in the main field as per the treatment details. The five randomly selected and tagged plants from the net plot were used to record the observations. Observations on plant growth, yield attributing traits, yield as well as resultant quality parameters were recorded. The data recorded were subjected to the statistical analysis as per Panse and Sukhatme.

\section{Results and Discussion}

The results pertaining to the effect of seeding interval and transplanting age of seedlings on plant height and days to $50 \%$ flowering are presented in table 1. Among the growth parameters the plant height did not vary significantly due to difference in seeding interval and transplanting age of seedlings, however the seedlings transplanted at the age of 18 days recorded numerically higher plant height $(76.59 \mathrm{~cm}$ and $77.98 \mathrm{~cm}$ in 2016 and 2017 respectively), whereas the total number of tillers as well as days to $50 \%$ flowering showed significant differences for 
transplanting age of seedlings, the seedlings transplanted at the age of 18 days recorded the higher number of total tillers as well as least number of days to $50 \%$ flowering (97.33 and 98.47 days in 2016 and 2017 respectively) compared to seedlings transplanted at the age of 25 days.

Similar to growth and flowering parameters the yield and yield attributing characters (Table 2 and 3 ) recorded significant variations for difference in transplanting age of seedlings as well as the seeding interval of parental lines. During both the years of experimentation the 18 days old seedlings recorded significantly highest number of productive tillers (9.47 and 10.52 in 2016 and 2017 respectively) than 25 days old seedlings (7.73 and 8.74 in 2016 and 2017 respectively). The highest seed set per cent $(11.47 \%$ and $11.90 \%$ in 2016 and 2017 respectively) and seed yield per hectare (838 $\mathrm{kg}, 888 \mathrm{~kg}$ in 2016 and 2017 respectively) compared to 25 days old seedlings with seed set per cent $(10.93 \%$ and $11.59 \%$ in 2016 and 2017 respectively) and seed yield per hectare $(788 \mathrm{~kg}, 831 \mathrm{~kg}$ in 2016 and 2017 respectively).

Similar to age of seedlings the seeding interval between parental lines also registered significant differences for yield parameters and among the seeding intervals, the highest seed set per cent (18.11\%, $18.54 \%$ in 2016 and 2017 respectively) and seed yield per hectare $(1170 \mathrm{~kg}, 1225 \mathrm{~kg}$ in 2016 and 2017 respectively) was noticed with the seeding interval of pollen parent 2 days earlier to seed parent, whereas the lowest seed set per cent (4.02 \%, $4.76 \%$ in 2016 and 2017 respectively) and seed yield per hectare (404 $\mathrm{kg}, 445 \mathrm{~kg}$ in 2016 and 2017 respectively) was noticed with the seeding interval of pollen parent 8 days earlier to seed parent. The interaction effect between transplanting age of seedlings and staggering of parental lines showed significant differences for seed yield per hectare. Among the interactions the $\mathrm{A}_{1} \mathrm{~S}_{2}$ recorded the significantly highest seed yield per hectare $(1190 \mathrm{~kg}$ and $1250 \mathrm{~kg}$ in 2016 and 2017 respectively) whereas the lowest seed yield per hectare $(390 \mathrm{~kg}$ and 426 $\mathrm{kg}$ in 2016 and 2017 respectively) was noticed with $\mathrm{A}_{2} \mathrm{~S}_{5}$.

The seed quality attributes influenced markedly by the difference in the transplanting ages of the rice seedlings. The staggering and interaction effects were found to be non-significant for the seed quality parameters (Table 3, 4 and 5). Transplanting of seedlings at the age of 18 days reported the highest seed quality parameters viz., seed germination per cent $(96.53 \%$ and $97.60 \%$ in 2016 and 2017 respectively), seedling shoot length $(12.93 \mathrm{~cm}$ and $13.21 \mathrm{~cm}$ in 2016, 2017 respectively), seedling root length $(15.39 \mathrm{~cm}$ and $16.08 \mathrm{~cm}$ in 2016 and 2017 respectively) and seedling vigour index (2734 and 2858 in 2016 and 2017 respectively).

Between the transplanting age of 18 days and 25 days old seedlings, 18 days old seedlings recorded the higher growth and flowering parameters higher plant height $(76.59 \mathrm{~cm}$ and $77.98 \mathrm{~cm}$ in 2016 and 2017 respectively), least number of days to $50 \%$ flowering (97.33 and 98.47 days in 2016 and 2017 respectively). This might be because of the shorter phyllochron interval in the young seedlings as well as the quick recovery from the transplanting stress and damages by the younger seedlings compared to old seedlings and also more vigorous growth and quick establishment of early transplanted seedlings ensured effective utilization of light, nutrients, space and other resources. These results are in confirmation with the findings of Pramanik and Bera (2013) in rice and Durga et al., (2015) in rice; Krishna et al., (2008) in rice and Qihua et al., (2017) in rice. 
The rate of tiller production in rice is faster from establishment to maximum tillering (3540 days of age) and slower thereafter, but tiller production continues until flowering. Huang et al., (1996) and Quyen et al., (2004) noticed that late grown tillers have a slower growth rate and died off due to insufficient supply of assimilates and nutrients in late transplanted seedlings. The negative tillering rate of rice in older seedlings and it was due to the death of adventitious tillers formed after panicle initiation in the peripheral circle of the rice plant. The highest seed set per cent $(18.11 \%, 18.54 \%$ in 2016 and 2017 respectively) and seed yield per hectare (1170 $\mathrm{kg}, 1225 \mathrm{~kg}$ in 2016 and 2017 respectively) was noticed with the seeding interval of pollen parent 2 days earlier to seed parent was mainly because of better synchronization (Fig. 1 and 2) of parental lines (Virmani and Sharma 1993) ensuring the effective out crossing there by increased seed set per cent and higher seed yield. The higher seed yield per hectare in 18 days old seedlings was mainly attributed to higher number of productive tillers The present results are in conformity with the findings of Siddiq et al., (1995) in rice; Joshi et al., (2002) in rice and Shiv Dayal et al., (2004) in rice.

The increase in the resultant seed quality parameters in the young age transplanted seedlings may be due to increased seed weight, higher dry matter accumulation through better source sink relationship produced more vigorous and viable seeds as the progressive reduction in the seedling dry matter accumulation increased with the increase of seedling age. The similar results were also reported by Chopra et al., (2002) in rice; Rahman (2004) and Kumar (2005) in rice.

Table.1 Effect of seedling age and seeding interval on plant height and days to 50 per cent flowering in seed parent (CRMS 32-A) of KRH-4 hybrid rice

\begin{tabular}{|c|c|c|c|c|c|c|c|c|c|c|c|c|}
\hline \multirow[t]{3}{*}{ Treatments } & \multicolumn{6}{|c|}{ Plant height (cm) } & \multicolumn{6}{|c|}{ Days to $50 \%$ flowering } \\
\hline & \multicolumn{3}{|c|}{2016} & \multicolumn{3}{|c|}{2017} & \multicolumn{3}{|c|}{$(2016)$} & \multicolumn{3}{|c|}{ (2017) } \\
\hline & $\mathbf{A}_{1}$ & $\mathbf{A}_{2}$ & Mean & $\mathbf{A}_{1}$ & $\mathbf{A}_{2}$ & Mean & $\mathbf{A}_{1}$ & $\mathbf{A}_{2}$ & Mean & $\mathbf{A}_{1}$ & $\mathbf{A}_{2}$ & Mean \\
\hline $\mathbf{S}_{1}$ & 76.71 & 76.95 & 76.83 & 78.04 & 78.62 & 78.33 & 97.33 & 99.33 & 98.33 & 98.33 & 100.67 & 99.50 \\
\hline $\mathbf{S}_{2}$ & 76.41 & 75.14 & 75.78 & 77.69 & 77.19 & 77.44 & 97.67 & 99.00 & 98.33 & 99.00 & 100.33 & 99.67 \\
\hline $\mathbf{S}_{\mathbf{3}}$ & 77.19 & 76.39 & 76.79 & 78.83 & 78.08 & 78.46 & 97.67 & 99.33 & 98.50 & 99.00 & 101.00 & 100.00 \\
\hline $\mathbf{S}_{4}$ & 76.65 & 76.13 & 76.39 & 77.98 & 77.73 & 77.86 & 97.00 & 98.67 & 97.83 & 98.00 & 100.33 & 99.17 \\
\hline $\mathbf{S}_{5}$ & 75.99 & 76.30 & 76.15 & 77.33 & 77.74 & 77.54 & 97.00 & 99.00 & 98.00 & 98.00 & 100.33 & 99.17 \\
\hline \multirow[t]{2}{*}{ Mean } & 76.59 & 76.18 & & 77.98 & 77.87 & & 97.33 & 99.07 & & 98.47 & 100.53 & \\
\hline & $\begin{array}{c}\text { S.Em. } \\
\pm\end{array}$ & $\begin{array}{l}\text { C.D. } \\
(0.05)\end{array}$ & & $\begin{array}{c}\text { S.Em. } \\
\pm\end{array}$ & $\begin{array}{c}\text { C.D. } \\
(\mathbf{0 . 0 5})\end{array}$ & & $\begin{array}{c}\text { S.Em. } \\
\pm\end{array}$ & $\begin{array}{c}\text { C.D. } \\
(\mathbf{0 . 0 5})\end{array}$ & & $\begin{array}{c}\text { S.Em. } \\
\pm\end{array}$ & $\begin{array}{c}\text { C.D. } \\
(\mathbf{0 . 0 5})\end{array}$ & \\
\hline $\mathbf{A}$ & 0.20 & NS & & 0.21 & NS & & 0.13 & 0.40 & & 0.16 & 0.49 & \\
\hline $\mathbf{S}$ & 0.32 & NS & & 0.34 & NS & & 0.21 & NS & & 0.26 & $\mathrm{NS}$ & \\
\hline $\mathbf{A} \times \mathbf{S}$ & 0.46 & NS & & 0.48 & NS & & 0.29 & NS & & 0.37 & NS & \\
\hline
\end{tabular}

S: Staggering of parental lines A: Transplanting age of seedlings

$\mathrm{S}_{1}$ : Same day planting of $\mathrm{A}$ and $\mathrm{R}$ lines $\mathrm{A}_{1:}$ Transplanting at the age of 18 days

$\mathrm{S}_{2}$ : early sowing of $\mathrm{R}$ line by 2 days $\quad \mathrm{A}_{2:}$ Transplanting at the age of 25 days

$\mathrm{S}_{3}$ : early sowing of $\mathrm{R}$ line by 4 days

$\mathrm{S}_{4}$ : early sowing of $\mathrm{R}$ line by 6 days

$\mathrm{S}_{5}$ : early sowing of $\mathrm{R}$ line by 8 days

NS- non-significant 
Table.2 Effect of seedling age and seeding interval on productive tillers and per cent seed set in seed parent (CRMS 32-A) of KRH-4 hybrid rice

\begin{tabular}{|c|c|c|c|c|c|c|c|c|c|c|c|c|}
\hline \multirow[t]{3}{*}{ Treatments } & \multicolumn{6}{|c|}{ Productive tillers } & \multicolumn{6}{|c|}{ Seed set per cent } \\
\hline & \multicolumn{3}{|c|}{2016} & \multicolumn{3}{|c|}{2017} & \multicolumn{3}{|c|}{ (2016) } & \multicolumn{3}{|c|}{ (2017) } \\
\hline & $\mathbf{A}_{1}$ & $\mathbf{A}_{2}$ & Mean & $\mathbf{A}_{1}$ & $\mathbf{A}_{2}$ & Mean & $\mathbf{A}_{1}$ & $\mathbf{A}_{2}$ & Mean & $\mathbf{A}_{1}$ & $\mathbf{A}_{2}$ & Mean \\
\hline $\mathbf{S}_{1}$ & 9.43 & 7.61 & 8.52 & 10.60 & 8.81 & 9.71 & 15.78 & 14.09 & 14.93 & 16.02 & 14.63 & 15.32 \\
\hline $\mathbf{S}_{2}$ & 9.53 & 8.13 & 8.83 & 10.39 & 8.93 & 9.66 & 18.84 & 17.39 & 18.11 & 19.29 & 17.78 & 18.54 \\
\hline $\mathbf{S}_{3}$ & 9.37 & 7.63 & 8.50 & 10.53 & 8.97 & 9.75 & 11.74 & 12.06 & 11.90 & 12.08 & 12.73 & 12.40 \\
\hline $\mathbf{S}_{4}$ & 9.47 & 7.57 & 8.52 & 10.60 & 8.40 & 9.50 & 6.97 & 7.11 & 7.04 & 7.38 & 8.01 & 7.70 \\
\hline $\mathbf{S}_{5}$ & 9.57 & 7.70 & 8.63 & 10.47 & 8.57 & 9.52 & 4.02 & 4.02 & 4.02 & 4.71 & 4.80 & 4.76 \\
\hline Mean & 9.47 & 7.73 & & 10.52 & 8.74 & & 11.47 & 10.93 & & 11.90 & 11.59 & \\
\hline & $\begin{array}{c}\text { S.Em. } \\
\pm\end{array}$ & $\begin{array}{l}\text { C.D. } \\
(0.05)\end{array}$ & & $\begin{array}{c}\text { S.Em. } \\
\pm\end{array}$ & $\begin{array}{l}\text { C.D. } \\
(0.05)\end{array}$ & & $\begin{array}{c}\text { S.Em. } \\
\pm\end{array}$ & $\begin{array}{l}\text { C.D. } \\
(\text { (0.05) }\end{array}$ & & $\begin{array}{c}\text { S.Em. } \\
\pm\end{array}$ & $\begin{array}{l}\text { C.D. } \\
(\text { (0.05) }\end{array}$ & \\
\hline $\mathbf{A}$ & 0.15 & 0.45 & & 0.10 & 0.30 & & 0.27 & NS & & 0.20 & NS & \\
\hline $\mathbf{S}$ & 0.24 & NS & & 0.15 & NS & & 0.43 & 1.27 & & 0.32 & 0.95 & \\
\hline $\mathbf{A} \times \mathbf{S}$ & 0.34 & NS & & 0.22 & NS & & 0.61 & NS & & 0.45 & NS & \\
\hline
\end{tabular}

S: Staggering of parental lines A: Transplanting age of seedlings

$\mathrm{S}_{1}$ : Same day planting of $\mathrm{A}$ and $\mathrm{R}$ lines $\mathrm{A}_{1:}$ Transplanting at the age of 18 days

$\mathrm{S}_{2}$ : early sowing of $\mathrm{R}$ line by 2 days $\mathrm{A}_{2:}$ Transplanting at the age of 25 days

$\mathrm{S}_{3}$ : early sowing of $\mathrm{R}$ line by 4 days

$\mathrm{S}_{4}$ : early sowing of $\mathrm{R}$ line by 6 days

$\mathrm{S}_{5}$ : early sowing of $\mathrm{R}$ line by 8 days

NS- non-significant

Table.3 Effect of seedling age and seeding interval on $\mathrm{F}_{1}$ seed yield per ha and seed germination percentage of $\mathrm{KRH}-4$ hybrid rice

\begin{tabular}{|c|c|c|c|c|c|c|c|c|c|c|c|c|}
\hline \multirow[t]{3}{*}{ Treatments } & \multicolumn{6}{|c|}{ Seed yield per ha (kg) } & \multicolumn{6}{|c|}{ Seed germination $(\%)$} \\
\hline & \multicolumn{3}{|c|}{2016} & \multicolumn{3}{|c|}{2017} & \multicolumn{3}{|c|}{ (2016) } & \multicolumn{3}{|c|}{ (2017) } \\
\hline & $\mathbf{A}_{1}$ & $\mathbf{A}_{2}$ & Mean & $\mathbf{A}_{1}$ & $\mathbf{A}_{2}$ & Mean & $\mathbf{A}_{1}$ & $\mathbf{A}_{2}$ & Mean & $\mathbf{A}_{1}$ & $\mathbf{A}_{2}$ & Mean \\
\hline $\mathbf{S}_{1}$ & 1094 & 1031 & 1063 & 1135 & 1073 & 1104 & 97.00 & 95.33 & 96.17 & 97.67 & 96.33 & 97.00 \\
\hline $\mathbf{S}_{2}$ & 1190 & 1151 & 1170 & 1250 & 1200 & 1225 & 96.67 & 94.67 & 95.67 & 97.67 & 96.00 & 96.83 \\
\hline $\mathbf{S}_{3}$ & 999 & 923 & 961 & 1056 & 974 & 1015 & 97.00 & 95.33 & 96.17 & 98.00 & 96.67 & 97.33 \\
\hline $\mathbf{S}_{4}$ & 489 & 444 & 467 & 533 & 484 & 508 & 96.00 & 95.33 & 95.67 & 97.33 & 96.00 & 96.67 \\
\hline $\mathbf{S}_{5}$ & 419 & 390 & 404 & 465 & 426 & 445 & 96.00 & 95.67 & 95.83 & 97.33 & 96.67 & 97.00 \\
\hline Mean & 838 & 788 & & 888 & 831 & & 96.53 & 95.27 & & 97.60 & 96.33 & \\
\hline & $\begin{array}{c}\text { S.Em. } \\
\pm\end{array}$ & $\begin{array}{c}\text { CD } \\
(0.05)\end{array}$ & & $\begin{array}{c}\text { S.Em. } \\
\pm\end{array}$ & $\begin{array}{c}\text { CD } \\
(0.05)\end{array}$ & & $\begin{array}{c}\text { S.Em. } \\
\pm\end{array}$ & $\begin{array}{c}\text { CD } \\
(0.05)\end{array}$ & & $\begin{array}{c}\text { S.Em. } \\
\pm\end{array}$ & $\begin{array}{c}\text { CD } \\
(0.05)\end{array}$ & \\
\hline $\mathbf{A}$ & 2.92 & 8.68 & & 2.97 & 8.82 & & 0.20 & 0.59 & & 0.15 & 0.45 & \\
\hline $\mathbf{S}$ & 4.62 & 13.72 & & 4.69 & 13.94 & & 0.32 & NS & & 0.24 & NS & \\
\hline $\mathbf{A} \times \mathbf{S}$ & 6.53 & 19.40 & & 6.64 & 19.72 & & 0.45 & NS & & 0.34 & NS & \\
\hline
\end{tabular}

S: Staggering of parental lines A: Transplanting age of seedlings

$\mathrm{S}_{1}$ : Same day planting of $\mathrm{A}$ and $\mathrm{R}$ lines $\mathrm{A}_{1:}$ Transplanting at the age of 18 days

$\mathrm{S}_{2}$ : early sowing of $\mathrm{R}$ line by 2 days

$\mathrm{A}_{2:}$ Transplanting at the age of 25 days

$\mathrm{S}_{3}$ : early sowing of $\mathrm{R}$ line by 4 days

$\mathrm{S}_{4}$ : early sowing of $\mathrm{R}$ line by 6 days

$\mathrm{S}_{5}$ : early sowing of $\mathrm{R}$ line by 8 days

NS- non-significant 
Table.4 Effect of seedling age and seeding interval on seedling shoot length and seedling root length of KRH-4 hybrid rice

\begin{tabular}{|c|c|c|c|c|c|c|c|c|c|c|c|c|}
\hline \multirow[t]{3}{*}{ Treatments } & \multicolumn{6}{|c|}{ Seedling shoot length $(\mathrm{cm})$} & \multicolumn{6}{|c|}{ Seedling root length $(\mathrm{cm})$} \\
\hline & \multicolumn{3}{|c|}{2016} & \multicolumn{3}{|c|}{2017} & \multicolumn{3}{|c|}{ (2016) } & \multicolumn{3}{|c|}{ (2017) } \\
\hline & $\mathbf{A}_{1}$ & $\mathbf{A}_{2}$ & Mean & $\mathbf{A}_{1}$ & $\mathbf{A}_{2}$ & Mean & $\mathbf{A}_{1}$ & $\mathbf{A}_{2}$ & Mean & $\mathbf{A}_{1}$ & $\mathbf{A}_{2}$ & Mean \\
\hline $\mathbf{S}_{1}$ & 12.93 & 12.17 & 12.55 & 13.26 & 12.53 & 12.89 & 15.30 & 14.93 & 15.11 & 16.27 & 15.64 & 15.96 \\
\hline $\mathbf{S}_{2}$ & 13.00 & 12.00 & 12.50 & 13.59 & 12.59 & 13.09 & 15.60 & 14.53 & 15.07 & 15.97 & 14.97 & 15.47 \\
\hline $\mathbf{S}_{\mathbf{3}}$ & 12.83 & 12.40 & 12.62 & 12.86 & 12.59 & 12.73 & 15.43 & 14.17 & 14.80 & 16.21 & 14.97 & 15.59 \\
\hline $\mathbf{S}_{\mathbf{4}}$ & 13.00 & 11.93 & 12.47 & 13.06 & 12.26 & 12.66 & 15.30 & 14.17 & 14.73 & 15.84 & 15.07 & 15.46 \\
\hline $\mathbf{S}_{5}$ & 12.90 & 12.07 & 12.48 & 13.26 & 12.13 & 12.69 & 15.30 & 14.33 & 14.82 & 16.11 & 14.97 & 15.54 \\
\hline Mean & 12.93 & 12.11 & & 13.21 & 12.42 & & 15.39 & 14.43 & & 16.08 & 15.13 & \\
\hline & $\begin{array}{c}\text { S.Em. } \\
\pm\end{array}$ & $\begin{array}{l}\text { C.D. } \\
(0.05)\end{array}$ & & $\begin{array}{l}\text { S.Em. } \\
\pm\end{array}$ & $\begin{array}{l}\text { C.D. } \\
\text { (0.05) }\end{array}$ & & $\begin{array}{c}\text { S. Em. } \\
\pm\end{array}$ & $\begin{array}{l}\text { C.D. } \\
(0.05)\end{array}$ & & $\begin{array}{c}\text { S.Em. } \\
\pm\end{array}$ & $\begin{array}{l}\text { C.D. } \\
(0.05)\end{array}$ & \\
\hline A & 0.13 & 0.39 & & 0.14 & 0.40 & & 0.09 & 0.26 & & 0.10 & 0.31 & \\
\hline $\mathbf{S}$ & 0.21 & NS & & 0.22 & NS & & 0.14 & NS & & 0.16 & NS & \\
\hline$A \times S$ & 0.29 & NS & & 0.30 & NS & & 0.20 & NS & & 0.23 & NS & \\
\hline
\end{tabular}

S: Staggering of parental lines A: Transplanting age of seedlings

$\mathrm{S}_{1}$ : Same day planting of $\mathrm{A}$ and $\mathrm{R}$ lines $\mathrm{A}_{1}$ : Transplanting at the age of 18 days

$\mathrm{S}_{2}$ : early sowing of $\mathrm{R}$ line by 2 days $\quad \mathrm{A}_{2}$ : Transplanting at the age of 25 days

$\mathrm{S}_{3}$ : early sowing of $\mathrm{R}$ line by 4 days

$\mathrm{S}_{4}$ : early sowing of $\mathrm{R}$ line by 6 days

$\mathrm{S}_{5}$ : early sowing of $\mathrm{R}$ line by 8 days

NS- non-significant

Table.5 Effect of seedling age and seeding interval on seedling vigour index of KRH-4 hybrid rice

\begin{tabular}{|c|c|c|c|c|c|c|}
\hline \multirow[t]{3}{*}{ Treatments } & \multicolumn{6}{|c|}{ Seedling vigour index } \\
\hline & \multicolumn{3}{|c|}{2016} & \multicolumn{3}{|c|}{2017} \\
\hline & $\mathbf{A}_{1}$ & $\mathbf{A}_{2}$ & Mean & $\mathbf{A}_{1}$ & $\mathbf{A}_{2}$ & Mean \\
\hline $\mathbf{S}_{1}$ & 2739 & 2583 & 2661 & 2884 & 2713 & 2799 \\
\hline $\mathbf{S}_{2}$ & 2765 & 2512 & 2638 & 2888 & 2646 & 2767 \\
\hline $\mathbf{S}_{3}$ & 2742 & 2533 & 2637 & 2849 & 2665 & 2757 \\
\hline$S_{4}$ & 2717 & 2488 & 2603 & 2813 & 2624 & 2718 \\
\hline $\mathbf{S}_{5}$ & 2707 & 2525 & 2616 & 2858 & 2619 & 2739 \\
\hline \multirow[t]{2}{*}{ Mean } & 2734 & 2528 & & 2858 & 2654 & \\
\hline & S. Em. \pm & C.D. $(0.05)$ & & S. Em. \pm & C.D. (0.05) & \\
\hline A & 14.98 & 44.51 & & 18.93 & 56.25 & \\
\hline $\mathbf{S}$ & 23.69 & NS & & 29.93 & NS & \\
\hline$A \times S$ & 33.50 & NS & & 42.33 & NS & \\
\hline
\end{tabular}

S: Staggering of parental lines A: Transplanting age of seedlings

$\mathrm{S}_{1}$ : Same day planting of $\mathrm{A}$ and $\mathrm{R}$ lines $\mathrm{A}_{1:}$ Transplanting at the age of 18 days

$\mathrm{S}_{2}$ : early sowing of $\mathrm{R}$ line by 2 days $\mathrm{A}_{2:}$ Transplanting at the age of 25 days

$\mathrm{S}_{3}$ : early sowing of $\mathrm{R}$ line by 4 days

$\mathrm{S}_{4}$ : early sowing of $\mathrm{R}$ line by 6 days

$\mathrm{S}_{5}$ : early sowing of $\mathrm{R}$ line by 8 days

NS- non-significant 
Fig.1 Synchronization of parental lines in $\mathrm{A}_{1} \mathrm{~S}_{2}$

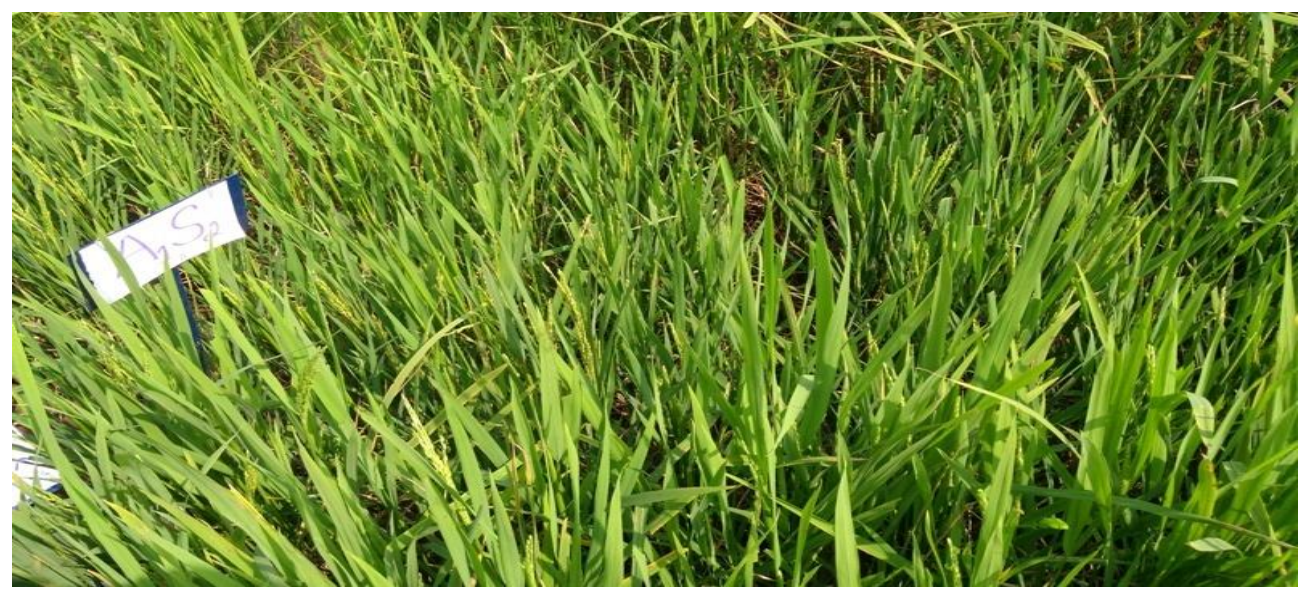

Fig.2 Lack of synchronization of parental lines in $\mathrm{A}_{1} \mathrm{~S}_{5}$

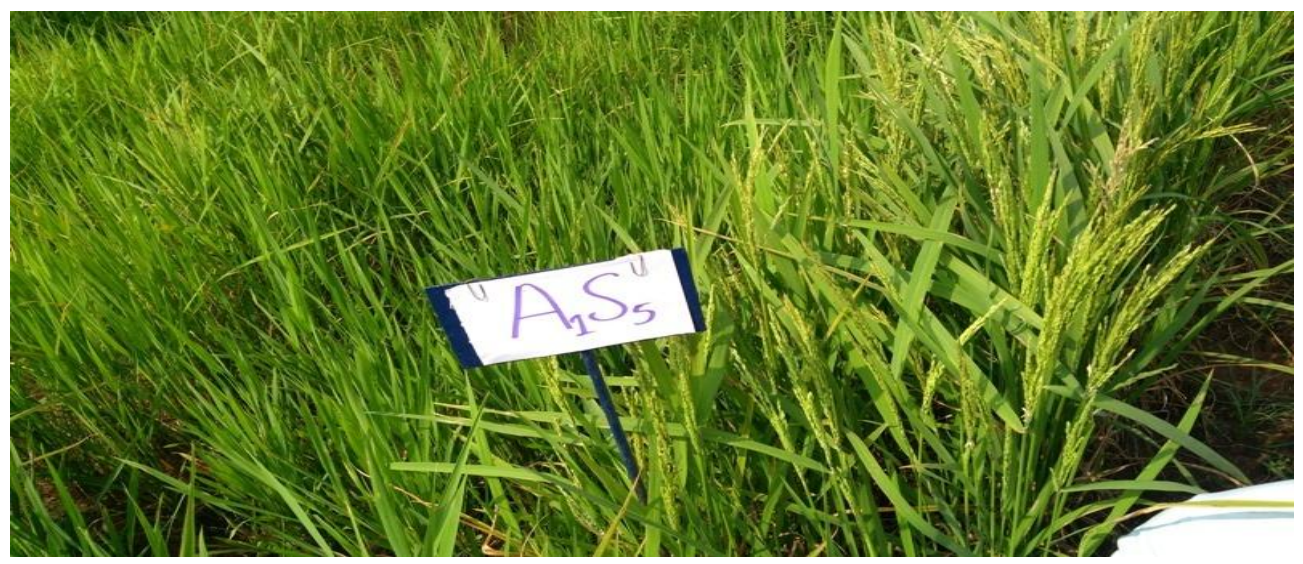

It is concluded that the present investigation revealed that transplanting of seedlings at the age of 18 days and staggering of male parent by 2 days early sowing ensures the higher number of productive tillers and better synchronization to get higher per cent seed set and higher seed yield in KRH-4 hybrid rice seed production under agro-climatic zone-9 (Hilly zone) of Karnataka (India).

\section{Acknowledgments}

The authors are thankful to the University of Agricultural Sciences, Dharwad (Karnataka), India for providing the necessary funds and facilities to undertake the present research work under Staff Research Project.

\section{References}

Biradarpatil, N. K. and Shekhargouda, M. 2006, Synchronization studies in Hybrid Rice. Karnataka J. Agric. Sci., 19(1): 298-303.

Chopra, N. K., J. P. Sinha, and Nisha Chopra., 2002, Effect of seedling age on seed yield and its quality in paddy Cv. Pusa 44. Seed Res., 30(1): 79-81.

Durga, K., P. Sambasiva Rao, and Raju, K. 2015, Effect of seedling age and 
spacing schedule on the productivity and quality traits of rice under system of rice intensification. $J$. Cereals and Oilseeds., 6 (3): 15-19.

Huang, Y., L. Gao, Z. Jin and Chen, H. 1996, A software package for optimizing rice production management based on growth simulation and feedback control. Agric. Systems., 50(4): 335354.

Joshi, B. K., L. P. Subedi, S. B. Gurung, and Sharma. R. C. 2002, Synchronization of flowering in rice. J. Inst. Agric. Sci., 23: 89-92

Krishna, A., N. K. Biradarpatil, K. Manjappa, and Channappagoudar, B. B. 2008, Evaluation of system of rice intensification cultivation, seedling age and spacing on seed yield and quality in Samba Masuhri (BPT-5204) Rice. Karnataka J. Agric. Sci., 21(1): 20-25.

Kumar, A. Y., 2005, Factor affecting seed yield and its quality in paddy cv. Mahamaya. M.Sc. (Ag) Thesis, IGKV, Raipur.

Panse, V. G. and Sukhatme, P. V. 1967, Statistical Methods for Agricultural Workers, ICAR Publication, New Delhi (India), pp. 167-174.

Pramanik, K. and Bera, A. K., 2013, Effect of seedling age and nitrogen fertilizer on growth, chlorophyll content, yield and economics of hybrid rice (Oryza sativa L.). Int. J. Agron. Pl. Prod., 4(5): 3489-3499.

Qihua, L., Z. Xuebiao, Jingling Li. and Caiyun Xin., 2017, Effects of seedling age and cultivation density on agronomic characteristics and grain yield of mechanically transplanted rice. Nature., 7: 1-10.

Quyen, N. V., P. S. Tan, C. V. Hach, P. V. $\mathrm{Du}$, and Zhong, X. 2004, Healthy rice canopy for optimal production and profitability. Omon rice, 12, 69-74.

Rahman, M., 2004, Optimum age of seedling for higher seed yield and seed quality in rice. Seed Res., 32(2): 134-137.

Shiv Dayal, P. K. Shrotria, J. S. Verma, and Rajendra, 2004, Flowering synchronization studies in hybrid rice (Pant Sankar Dhan- 1) seed production. Pantnagar J. Res., 2 (1): 22-24.

Siddiq, E. A., B. C. Ilyas Ahmed, Viraktamath, A. Jauhar, and Hoan, N. T., 1995, Status of hybrid rice research in India. In: Hybrid Research and Development. Indian Society of Seed Technol, New Delhi. Pp. 139-158.

Virmani, S. S. and Sharma, H. L., 1993, Manual for hybrid rice seed production, IRRI. Manila. Philipphines, Pp. 72.

\section{How to cite this article:}

Madhukeshwara, B., Puttappanavara, V.K. Deshpande, A. Krishna and Hanumaratti, N.G. 2019. Effect of Seeding Interval and Transplanting Age on Seed Yield and Seed Quality in KRH-4 Hybrid Rice. Int.J.Curr.Microbiol.App.Sci. 8(02): 456-463. doi: https://doi.org/10.20546/ijcmas.2019.802.051 